Check for updates

Cite this: RSC Adv., 2019, 9, 28894

\title{
Facile one-pot synthesis of $\mathrm{Mg}$-doped $\mathrm{g}-\mathrm{C}_{3} \mathrm{~N}_{4}$ for photocatalytic reduction of $\mathrm{CO}_{2}^{\dagger}$
}

\author{
Xinyue Dong, ${ }^{a}$ Suicai Zhang, ${ }^{\mathrm{b}}$ Hualin Wu, ${ }^{\mathrm{b}}$ Zhuo Kang (D) *bc and Li Wang ${ }^{\star a d}$
}

Graphitic carbon nitride $\left(\mathrm{g}-\mathrm{C}_{3} \mathrm{~N}_{4}\right)$ has attracted wide attention due to its potential in solving energy and environmental issues. However, rapid charge recombination and a narrow visible light absorption region limit its performance. In our study, $\mathrm{Mg}$-doped $\mathrm{g}-\mathrm{C}_{3} \mathrm{~N}_{4}$ was synthesized through a facile one-pot strategy for $\mathrm{CO}_{2}$ reduction. After $\mathrm{Mg}$ doping, the light utilization efficiency and photo-induced electron-hole pair separation efficiency of the catalysts were improved, which could be due to the narrower band gap and introduced midgap states. The highest amounts of $\mathrm{CO}$ and $\mathrm{CH}_{4}$ were obtained on $\mathrm{Mg}-\mathrm{CN}-4 \%$ under ultraviolet light illumination, which were about 5.1 and 3.8 times that of pristine $\mathrm{g}-\mathrm{C}_{3} \mathrm{~N}_{4}$, respectively; the yield of $\mathrm{CO}$ and $\mathrm{CH}_{4}$ reached 12.97 and $7.62 \mu \mathrm{mol} \mathrm{g}{ }^{-1}$ under visible light irradiation. Our work may provide new insight for designing advanced photocatalysts in energy conversion applications.

Received 19th June 2019

Accepted 4th September 2019

DOI: $10.1039 / c 9 r a 04606 b$

rsc.li/rsc-advances
Strategies for $\mathrm{g}-\mathrm{C}_{3} \mathrm{~N}_{4}$ modification, including metal doping $\left(\mathrm{K},{ }^{21} \mathrm{Cu},{ }^{22} \mathrm{Pd},{ }^{23} \mathrm{Mn}^{24}\right)$, non-metal doping $\left(\mathrm{B},{ }^{25} \mathrm{~N},{ }^{26} \mathrm{~S}^{27} \mathrm{P}^{28}\right)$, semiconductor recombination $\left(\mathrm{V}_{2} \mathrm{O}_{5},{ }^{29} \mathrm{MnO}_{2},{ }^{30} \mathrm{CeO}_{2},{ }^{31} \mathrm{TiO}_{2}\right.$ (ref. 32)), and so on, have been developed to suppress the recombination of photo-generated electron-hole pairs, expand the visible light response range, and improve the photocatalytic performance. ${ }^{33,34}$ Among these strategies, element doping was a hot research. For example, Kumar et al. synthesized Se-doped g- $\mathrm{C}_{3} \mathrm{~N}_{4}$ by facile one-pot two-step strategy and the catalysts demonstrated high photocatalytic performance in $\mathrm{CO}_{2}$ reduction. ${ }^{35}$ Wang et al. synthesized K-doped $\mathrm{g}-\mathrm{C}_{3} \mathrm{~N}_{4}$ by thermal polymerization, and the photocatalytic hydrogen evolution rate of K-doped g- $\mathrm{C}_{3} \mathrm{~N}_{4}$ was improved. ${ }^{21}$ Tang et al. synthesized $\mathrm{Mg} / \mathrm{g}$ $\mathrm{C}_{3} \mathrm{~N}_{4}$ by hydrothermal deposition method and the results show that $\mathrm{Mg}$ element plays an important role in increasing electronholes pairs separation and extending the range of light response. ${ }^{36}$ However, doping of $\mathrm{Mg}$ into carbon nitride by onepot method has not been explored so far.

In this manuscript, Mg-doped $\mathrm{g}-\mathrm{C}_{3} \mathrm{~N}_{4}$ photocatalysts with various doping amount have been successfully prepared by onepot method with magnesium chloride as $\mathrm{Mg}$ source. The catalysts were characterized by a series of methods such as, XRD, TEM, XPS, UV-vis, and PL. The catalytic performance towards photocatalytic $\mathrm{CO}_{2}$ reduction was evaluated in the gas phase reactor.

\section{Results and discussion}

The morphologies of samples were observed by SEM. As shown in Fig. 1(a), the SEM image of $\mathrm{g}-\mathrm{C}_{3} \mathrm{~N}_{4}$ displays typical twodimensional layered structure with wrinkles and irregular stacks. ${ }^{37}$ After doping Mg (Fig. 1(b)), the morphology of g- $\mathrm{C}_{3} \mathrm{~N}_{4}$ changes to some extent, which may be attributed to 

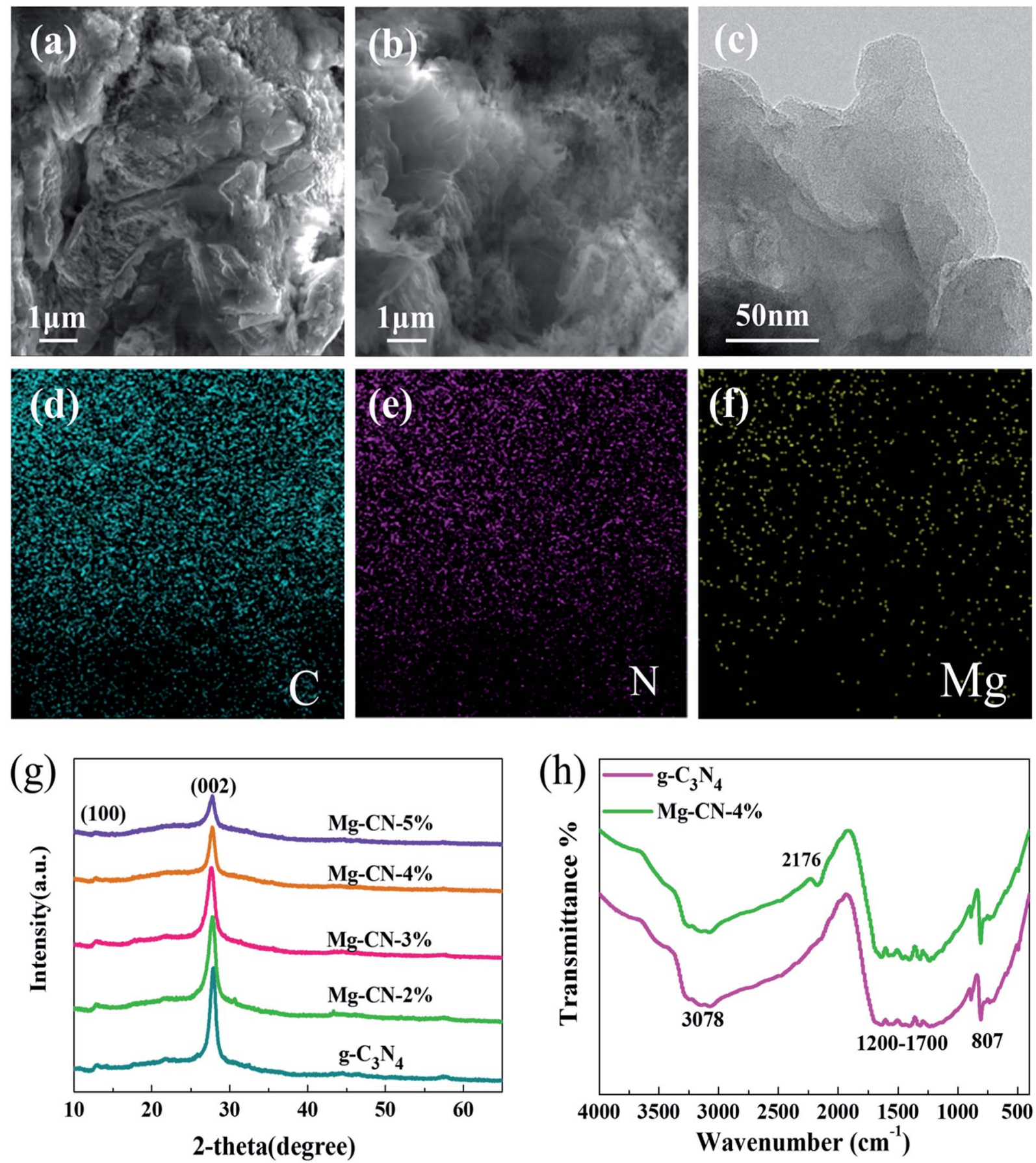

Fig. 1 SEM images of (a) $\mathrm{g}-\mathrm{C}_{3} \mathrm{~N}_{4}$, (b) $\mathrm{Mg}-\mathrm{CN}-4 \%$; (c) TEM image of $\mathrm{Mg}-\mathrm{CN}-4 \%$; (d) elemental mapping images of C, (e) $\mathrm{N}$, (f) $\mathrm{Mg}$ of $\mathrm{Mg}-\mathrm{CN}-4 \%$; (g) XRD spectra of samples; (h) FTIR spectra of $\mathrm{g}-\mathrm{C}_{3} \mathrm{~N}_{4}$ and $\mathrm{Mg}-\mathrm{CN}-4 \%$.

delamination effect. ${ }^{38}$ Compared with $\mathrm{g}-\mathrm{C}_{3} \mathrm{~N}_{4}$, the layers of $\mathrm{Mg}$ $\mathrm{CN}-4 \%$ become thinner and curlier. The $\mathrm{Mg}-\mathrm{CN}-4 \%$ having optimum photocatalytic activity was selected for TEM characterization. The TEM image of $\mathrm{Mg}-\mathrm{CN}-4 \%$ shows a typical layered structure in Fig. 1(c). ${ }^{39}$ The EDX spectrum (Fig. S1†) and elemental mapping of the $\mathrm{Mg}-\mathrm{CN}-4 \%$ indicates that the sample consisted of $\mathrm{C}, \mathrm{N}$ and $\mathrm{Mg}$ elements.

The crystalline structures of samples were analyzed by XRD. Fig. $1(\mathrm{~g})$ shows XRD patterns of g- $\mathrm{C}_{3} \mathrm{~N}_{4}$ and $\mathrm{Mg}$-doped g- $\mathrm{C}_{3} \mathrm{~N}_{4}$. For g- $\mathrm{C}_{3} \mathrm{~N}_{4}$ sample, there are two typical diffraction peaks at $12.86^{\circ}$ and $27.79^{\circ}$ corresponding to (100) and (002) facet of $\mathrm{g}-\mathrm{C}_{3} \mathrm{~N}_{4}$. The peak at $12.86^{\circ}$ is assigned to in-plane repeating tri-s-triazine units, and the sharp peak at $27.79^{\circ}$ is ascribed to interlayer stacking of conjugated aromatics. ${ }^{40}$ Mg-doped g- $\mathrm{C}_{3} \mathrm{~N}_{4}$ has similar diffraction peaks with g- $\mathrm{C}_{3} \mathrm{~N}_{4}$, indicating that $\mathrm{Mg}$ doping does not change the graphiticlike structure of $\mathrm{g}-\mathrm{C}_{3} \mathrm{~N}_{4}$. No diffraction peaks of the $\mathrm{Mg}$ species were observed in the $\mathrm{Mg}-\mathrm{CN}-4 \%$, manifesting that 
$\mathrm{Mg}$ was successfully doped into $\mathrm{g}-\mathrm{C}_{3} \mathrm{~N}_{4}$. After doping $\mathrm{Mg}$, the peak intensity of the catalyst decreases, indicating that $\mathrm{Mg}$ doping can reduce the crystallinity of $\mathrm{g}-\mathrm{C}_{3} \mathrm{~N}_{4} \cdot{ }^{41}$

The doping state and bonding characteristics of $\mathrm{g}-\mathrm{C}_{3} \mathrm{~N}_{4}$ and Mg-CN-4\% was confirmed by FTIR spectra. In Fig. 1(h), the representative peak appeared at $807 \mathrm{~cm}^{-1}$ belonged to the characteristic breathing vibration mode for tri-s-triazine rings of $\mathrm{g}-\mathrm{C}_{3} \mathrm{~N}_{4},{ }^{42}$ and the peaks at $1200-1700 \mathrm{~cm}^{-1}$ are ascribed to the typical CN heterocycles stretching modes. ${ }^{43}$ The peaks at $1240-$ $1400 \mathrm{~cm}^{-1}$ and $1480-1650 \mathrm{~cm}^{-1}$ are assigned to the stretching modes of $\mathrm{C}-\mathrm{N}$ and $\mathrm{C}=\mathrm{N}$ groups, respectively. ${ }^{21}$ Another broad peak at around $3078 \mathrm{~cm}^{-1}$ is caused by $\mathrm{N}-\mathrm{H}$ bonds, which is derived from uncondensed amine groups. ${ }^{44}$ Compared with $\mathrm{g}$ $\mathrm{C}_{3} \mathrm{~N}_{4}$, a distinct peak appeared at $2176 \mathrm{~cm}^{-1}$ in $\mathrm{Mg}-\mathrm{CN}-4 \%$, which can be attributed to $\mathrm{C} \equiv \mathrm{N}$ group. Due to $\mathrm{Mg}$-induced surface defects, some $\mathrm{sp}^{2} \mathrm{C}-\mathrm{N}$ bonds were converted into $\mathrm{C} \equiv \mathrm{N}$ bonds in $\mathrm{Mg}-\mathrm{CN}-4 \%{ }^{45,46}$

To further examine the surface chemical composition and elemental valence of samples, XPS measurements was performed. Fig. 2(a) illustrates XPS survey spectra of $\mathrm{g}-\mathrm{C}_{3} \mathrm{~N}_{4}$ and $\mathrm{Mg}-\mathrm{CN}-4 \%$, elements of $\mathrm{C}, \mathrm{N}, \mathrm{O}$ were detected in both catalysts. $\mathrm{Mg}$ elements can be observed in $\mathrm{Mg}-\mathrm{CN}-4 \%$, which is consistent with the results of XRD. The N1s peaks of g$\mathrm{C}_{3} \mathrm{~N}_{4}$ can be deconvoluted into four characteristic peaks with binding energy at $398.68 \mathrm{eV}, 399.35 \mathrm{eV}, 400.87 \mathrm{eV}$, and $404.61 \mathrm{eV}$, respectively (Fig. 2(b)). The most intense peak was at $398.68 \mathrm{eV}$, corresponding to $\mathrm{sp}^{2}$ hybridized $\mathrm{N}$ in $\mathrm{C}-\mathrm{N}=\mathrm{C}$ groups. The peaks at $399.35 \mathrm{eV}$ and $400.87 \mathrm{eV}$ are ascribed to tertiary $\mathrm{N}$ atoms bonded of $\mathrm{N}-(\mathrm{C})_{3}$ groups and amino functional groups ${ }^{47}$ and the peak at $404.61 \mathrm{eV}$ is attributed to typical $\pi$-excitations in the heterocycles. The C1s spectra of $\mathrm{g}-\mathrm{C}_{3} \mathrm{~N}_{4}$ are shown in Fig. 2(c), from which two peaks can be observed at $284.94 \mathrm{eV}$ and $288.25 \mathrm{eV}$, corresponding to $\mathrm{C}-\mathrm{C}$ bonds and $\mathrm{N}-\mathrm{C}-\mathrm{N}$ coordination in the graphitic structure, respectively. ${ }^{48}$ The $\mathrm{Mg} 2 \mathrm{p}$ binding energy is $50.81 \mathrm{eV}$, which usually belongs to $\mathrm{Mg}^{2+} \cdot{ }^{49,50}$ In the O1s XPS spectra (Fig. S2†), no peaks appeared at $\sim 528-531 \mathrm{eV}$, which correspond to $\mathrm{O}$ in metal oxides. ${ }^{23}$ Therefore, magnesium is doped into the $\mathrm{CN}$ skeleton in an ionic state. Compared with $\mathrm{g}-\mathrm{C}_{3} \mathrm{~N}_{4}$, the $\mathrm{C} 1 \mathrm{~s}$ and N1s peaks of $\mathrm{Mg}-\mathrm{CN}-4 \%$ show a slight shift, indicating that the surface chemical structure of Mg-doped g- $\mathrm{C}_{3} \mathrm{~N}_{4}$ changes. ${ }^{51}$

The optical absorption properties of $\mathrm{g}-\mathrm{C}_{3} \mathrm{~N}_{4}$ and $\mathrm{Mg}-\mathrm{CN}-$ $4 \%$ were studied by UV-vis diffuse reflectance spectra. As
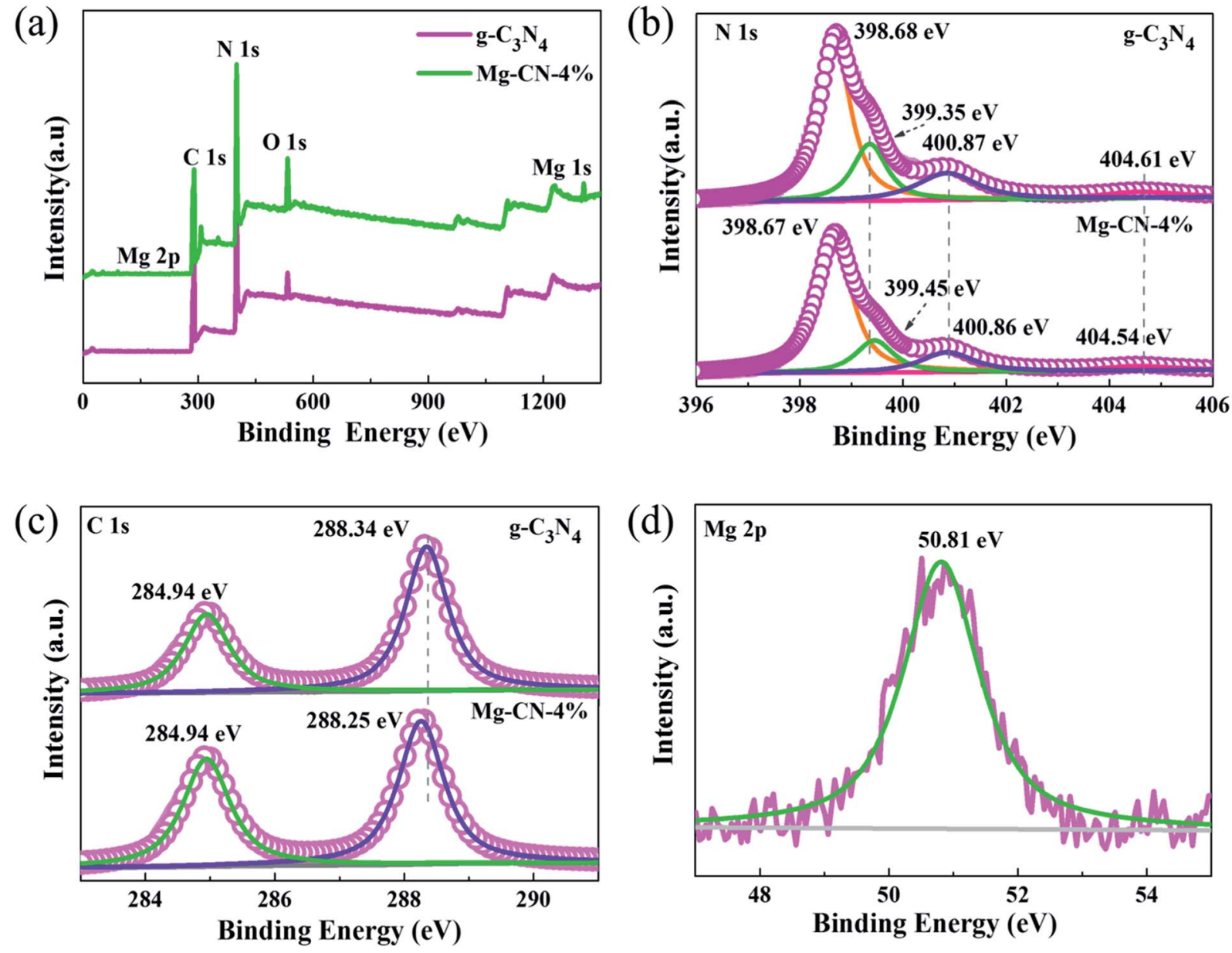

Fig. 2 (a) Wide survey scans, (b) N1s high-resolutions, (c) C1s high-resolutions of g- $\mathrm{C}_{3} \mathrm{~N}_{4}$ and $\mathrm{Mg}-\mathrm{CN}-4 \%$, (d) Mg2p high-resolutions of $\mathrm{Mg}-\mathrm{CN}-$ $4 \%$. 
(a)
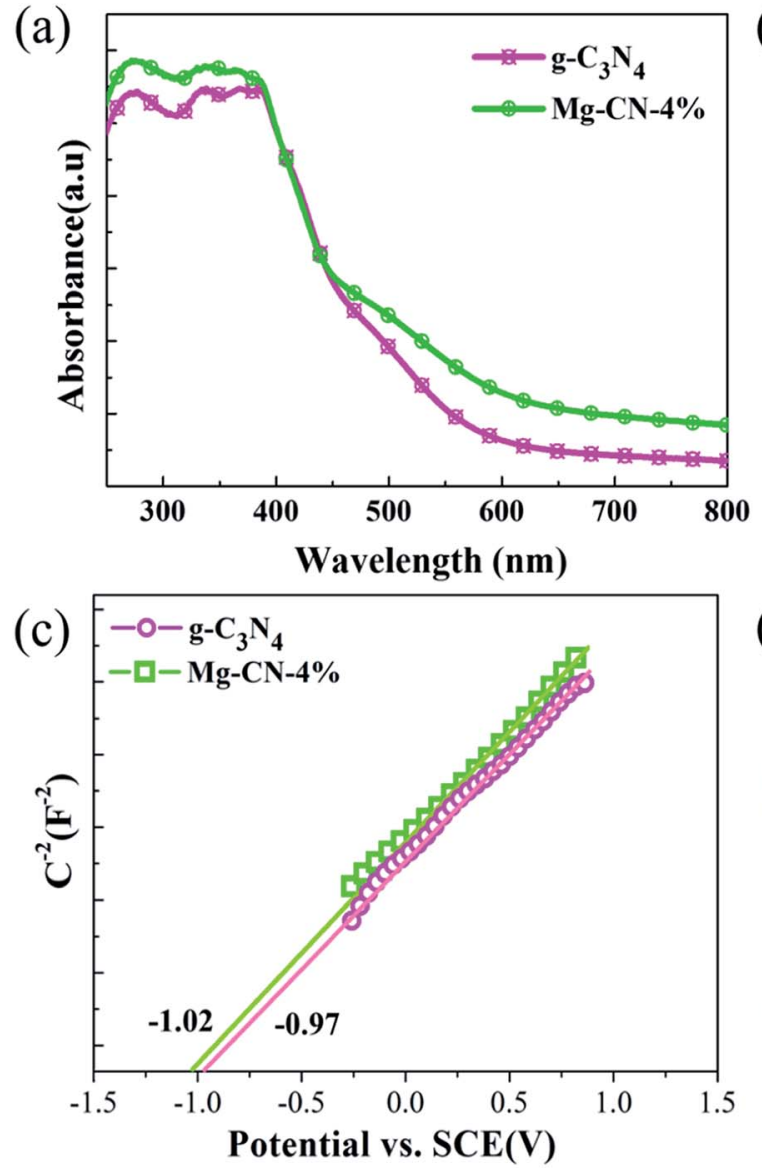

(b)

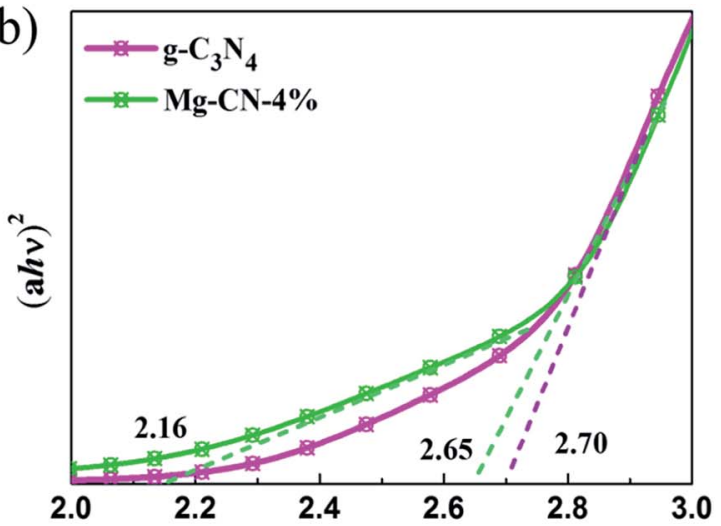

(d)

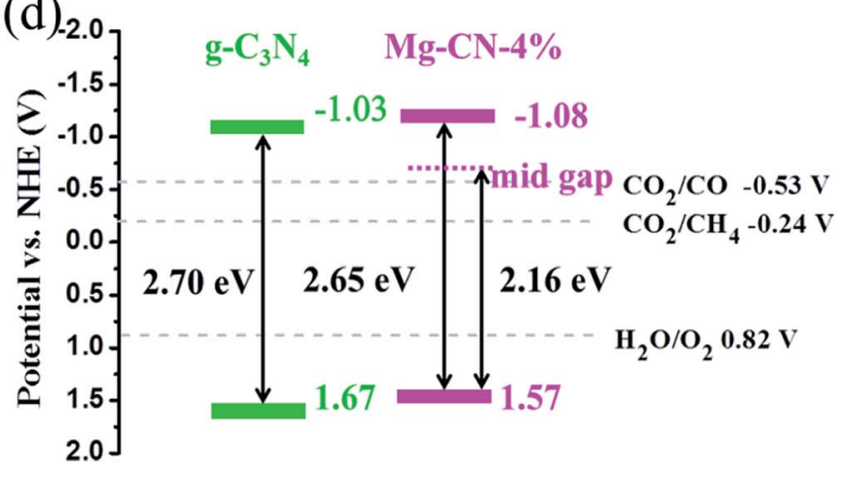

Fig. 3 (a) UV-vis diffuse reflectance spectra, (b) the plots of $(a h v)^{2}$ versus $h \nu$ for the band gap energies, (c) Mott-Schottky plots, (d) band gap structure of $\mathrm{g}-\mathrm{C}_{3} \mathrm{~N}_{4}$ and $\mathrm{Mg}-\mathrm{CN}-4 \%$.

seen in Fig. 3(a), the intensity of light absorption of Mg-CN$4 \%$ was higher than $\mathrm{g}-\mathrm{C}_{3} \mathrm{~N}_{4}$ from ultraviolet light to visible light region. The optical band gap energies of as-prepared photocatalysts have been calculated by using the following formula:

$$
a h \nu=A\left(h \nu-E_{\mathrm{g}}\right)^{n}
$$

where $a, h, \nu, A$ and $E_{\mathrm{g}}$ are the absorption coefficient, Planck's constant, light frequency, proportionality constant and bandgap, respectively. ${ }^{52}$ The optical band gap energies for samples were obtained from a plot of $(a h v)^{2} v s . h \nu(n=1 / 2$ for a direct transition, $n=2$ for an indirect transition). As shown in Fig. 4(b), the band gap of $\mathrm{g}-\mathrm{C}_{3} \mathrm{~N}_{4}$ was estimated to be $2.70 \mathrm{eV}$, which is equal to the band gap in the previously reported paper. ${ }^{53}$ It is clearly revealed that $\mathrm{Mg}$ doping reduced the band gap of $\mathrm{Mg}-\mathrm{CN}-4 \%$ to $2.65 \mathrm{eV}$. The UV-vis spectra of Mg-CN- $4 \%$ presented a tail absorption which indicates the formation of the midgap states. ${ }^{35}$ It is reported that such midgap states is due to the existence of disorders/defects within the band gap. ${ }^{54}$ The Mott-Schottky curves of $\mathrm{g}-\mathrm{C}_{3} \mathrm{~N}_{4}$ and $\mathrm{Mg}-\mathrm{CN}-4 \%$ are shown in Fig. 3(c). The flat band potentials of g- $\mathrm{C}_{3} \mathrm{~N}_{4}$ and $\mathrm{Mg}-\mathrm{CN}-4 \%$ were confirmed as $-0.97 \mathrm{~V}$ and $-1.02 \mathrm{~V} v$ s. SCE, which correspond to $-0.73 \mathrm{~V}$ and $-0.78 \mathrm{~V} v s$. NHE, respectively. According to the rule of thumb, the conduction band (CB) is more negative by about $-0.3 \mathrm{eV}$ than the flat band potential. ${ }^{42} \mathrm{The} \mathrm{CB}$ of $\mathrm{g}-\mathrm{C}_{3} \mathrm{~N}_{4}$ and $\mathrm{Mg}$ $\mathrm{CN}-4 \%$ could be estimated to be $-1.03 \mathrm{~V}$ and $-1.08 \mathrm{~V}$. According to their band gap, the valence band (VB) position of $\mathrm{g}$ $\mathrm{C}_{3} \mathrm{~N}_{4}$ and $\mathrm{Mg}-\mathrm{CN}-4 \%$ can be calculated as $1.67 \mathrm{~V}$ and $1.57 \mathrm{~V}$, respectively. Combined UV-vis spectrum with the Mott-Schottky curves, Fig. 3(d) shows the VB and CB positions of Mg-CN-4\%. The midgap states energy from VB to midgap states for $\mathrm{Mg}-\mathrm{CN}$ $4 \%$ was determined to be $2.16 \mathrm{eV}$. Therefore, the exact position of midgap states for $\mathrm{Mg}-\mathrm{CN}-4 \%$ was calculated as $-0.59 \mathrm{~V}$, which is higher than $\mathrm{CO}_{2}$ reduction level $\left(\mathrm{CO}_{2} / \mathrm{CO},-0.53 \mathrm{~V} v \mathrm{~s}\right.$. $\mathrm{NHE} ; \mathrm{CO}_{2} / \mathrm{CH}_{4},-0.24 \mathrm{~V}$ vs. NHE). Due to the presence of midgap states, $\mathrm{Mg}$-CN- $4 \%$ could harvest long-wavelength visible light to stimulate electrons in the VB to midgap states..$^{55,56}$ Moreover, the excited electrons in CB could be temporarily trapped by midgap states to suppress electron-hole pairs recombination..$^{57,58}$

PL analysis is commonly performed to study the migration, transfer and recombination of electron-hole pairs produced by the photocatalyst. The PL spectra of $\mathrm{g}-\mathrm{C}_{3} \mathrm{~N}_{4}$ and $\mathrm{Mg}-\mathrm{CN}-4 \%$ with excitation wavelength of $325 \mathrm{~nm}$ are shown in Fig. 4(a). It can be seen that the spectra of $\mathrm{Mg}-\mathrm{CN}-4 \%$ is similar to $\mathrm{g}-\mathrm{C}_{3} \mathrm{~N}_{4}$ with a strong peak around $465 \mathrm{~nm}$. When 
(a)
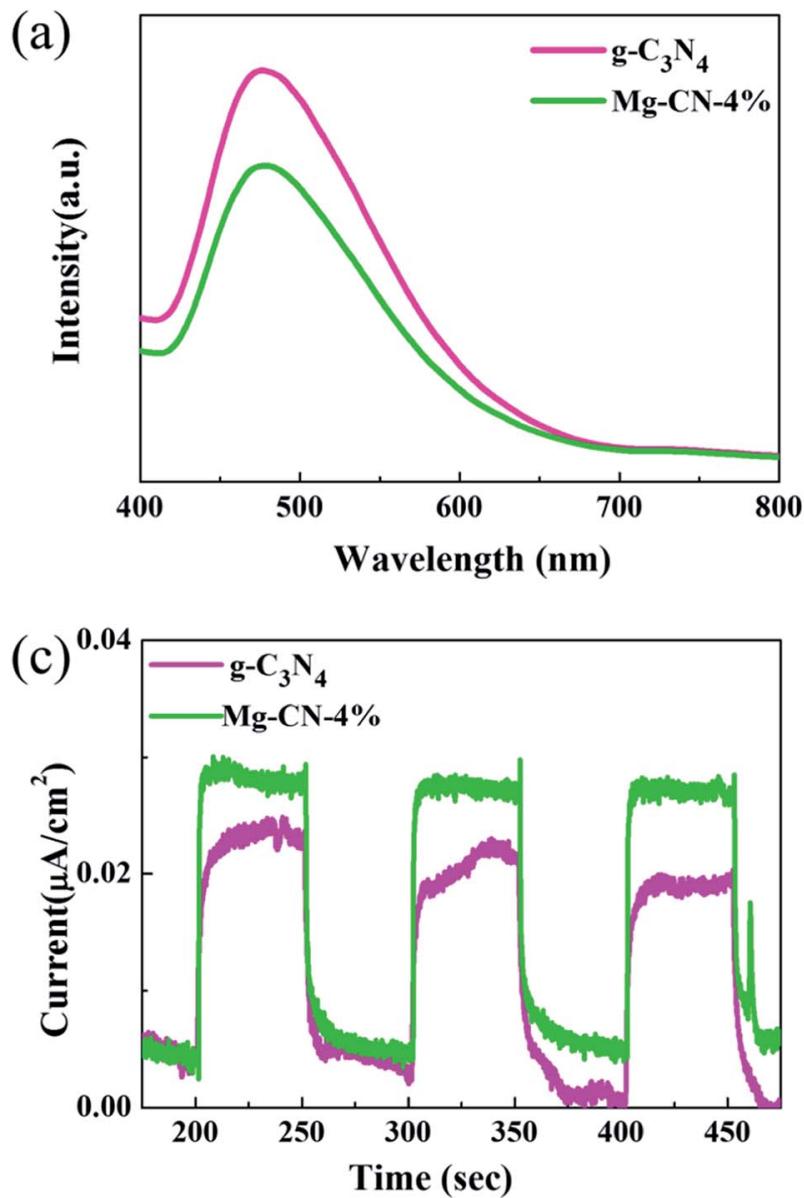
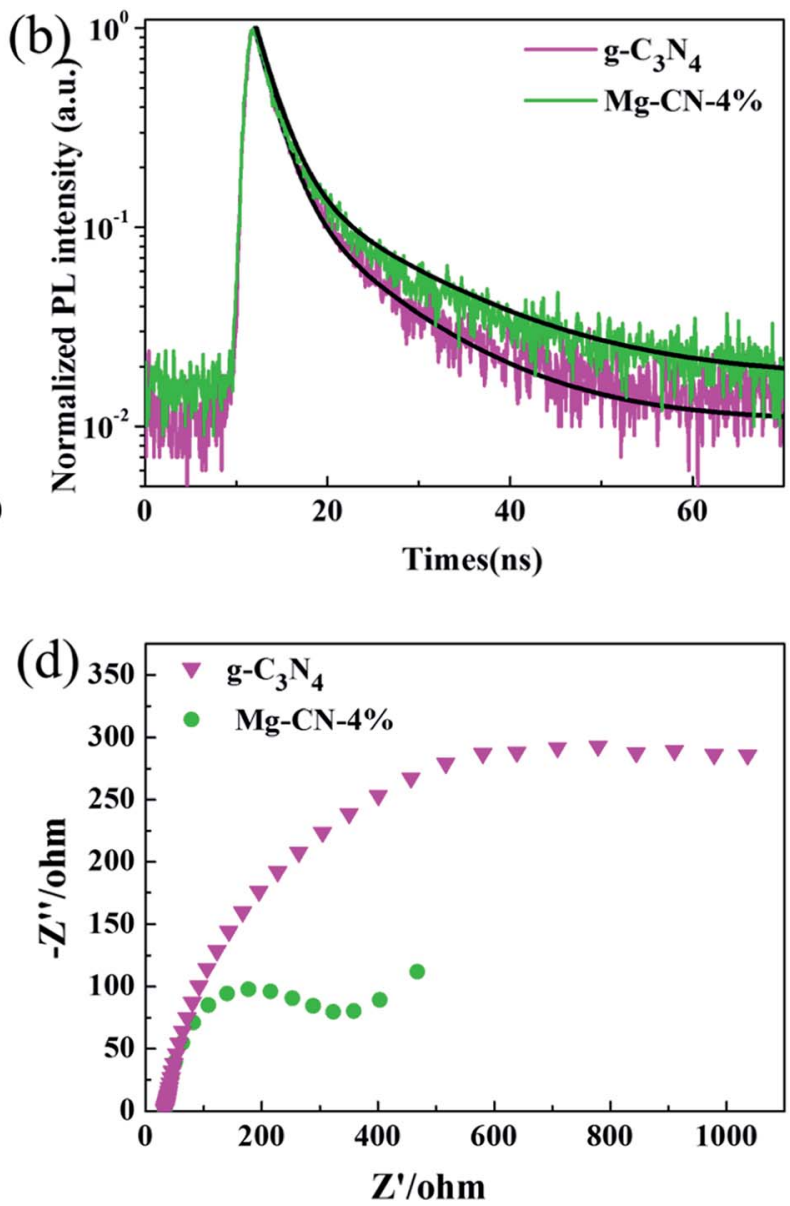

Fig. 4 (a) Photoluminescence spectra, (b) time-resolved PL spectra, (c) transient photocurrent-time curves, (d) electrochemical impedance spectra of $\mathrm{g}-\mathrm{C}_{3} \mathrm{~N}_{4}$ and $\mathrm{Mg}-\mathrm{CN}-4 \%$.

$\mathrm{Mg}$ was added, the PL intensity clearly decreases, indicating that $\mathrm{Mg}$-doped $\mathrm{g}-\mathrm{C}_{3} \mathrm{~N}_{4}$ can suppress the recombination of photo-generated electron-hole pairs. The midgap states might act as the center for entrapment of electrons, and enhances photocatalytic activity of catalyst. ${ }^{35}$ As displayed in Fig. 4(b), a longer recombination lifetime of $\mathrm{Mg}$ doped g$\mathrm{C}_{3} \mathrm{~N}_{4}$ was examined by time-resolved photoluminescence, indicating that the recombination of carriers was suppressed, which is consistent with the PL results.

Fig. 4(c) shows the transient photocurrent-time $(I-t)$ curves for two samples with interval $50 \mathrm{~s}$ light on/off cycle of visible light irradiation. Notably, photocurrent intensity of $\mathrm{Mg}-\mathrm{CN}-4 \%$ reached $0.028 \mu \mathrm{A} \mathrm{cm}^{-2}$, which is higher than that of g- $\mathrm{C}_{3} \mathrm{~N}_{4}$. The photocurrent intensity sharply increased from the light-off to light-on state, which is attributed to fast photo-generated electrons transport on the sample surface. ${ }^{59}$ Hence, a higher photocurrent response indicates a lower electron-hole recombination. Fig. 4(d) shows electrochemical impedance spectroscopy of $\mathrm{g}-\mathrm{C}_{3} \mathrm{~N}_{4}$ and $\mathrm{Mg}-\mathrm{CN}-4 \%$. It can be clearly observed that the arc radius of EIS Nyquist plot become smaller after doping $\mathrm{Mg}$, which reflects more effective separation of electron-hole pairs. ${ }^{60}$

\section{Evaluation of photocatalytic activity}

The ultraviolet photocatalytic activity of g- $\mathrm{C}_{3} \mathrm{~N}_{4}$ and g- $\mathrm{C}_{3} \mathrm{~N}_{4}$ doped with different magnesium amount are shown in Fig. 5(a) and (b). Under the combined action of ultraviolet irradiation, water vapor and carbon dioxide, the products of $\mathrm{CO}$ and $\mathrm{CH}_{4}$ were detected by gas chromatography after $8 \mathrm{~h}$ photocatalytic reaction, and the accumulation of $\mathrm{CO}$ was much higher than that of $\mathrm{CH}_{4}$. The optimum doping amount of the samples is $\mathrm{Mg}-\mathrm{CN}-4 \%$, and the yield of $\mathrm{CO}$ and $\mathrm{CH}_{4}$ can reach up to 57.90 and $9.12 \mu \mathrm{mol} \mathrm{g}^{-1}$, which is 5.1 and 3.8 times of that produced by g- $\mathrm{C}_{3} \mathrm{~N}_{4}$. When $\mathrm{Mg}-\mathrm{CN}-2 \%$, $\mathrm{Mg}-\mathrm{CN}-3 \%, \mathrm{Mg}-\mathrm{CN}-5 \%$ were used as catalysts, the accumulation of CO can reach to $25.35,47.23,26.54 \mu \mathrm{mol} \mathrm{g}^{-1}$, and the yield of $\mathrm{CH}_{4}$ is $4.66,8.25,5.49 \mu \mathrm{mol} \mathrm{g}^{-1}$. The visible light photocatalytic activity of $\mathrm{g}-\mathrm{C}_{3} \mathrm{~N}_{4}$ and $\mathrm{Mg}-\mathrm{CN}-4 \%$ is shown in Fig. 5(c). After $8 \mathrm{~h}$ of visible light irradiation, the yield of $\mathrm{CO}$ were $6.35,12.97 \mu \mathrm{mol} \mathrm{g}^{-1}$, and yield of $\mathrm{CH}_{4}$ were 2.01 and $7.62 \mu \mathrm{mol} \mathrm{g^{-1 }}$, respectively.

According to the analysis above, the light utilization efficiency of the $\mathrm{g}-\mathrm{C}_{3} \mathrm{~N}_{4}$ has been improved after $\mathrm{Mg}$ doping, which could due to the narrowed down band gap and introduced midgap states. The proper amount of $\mathrm{Mg}$ doping can suppress the recombination of photo-induced electron-hole pairs, thus improving photocatalytic activity. 
(a)

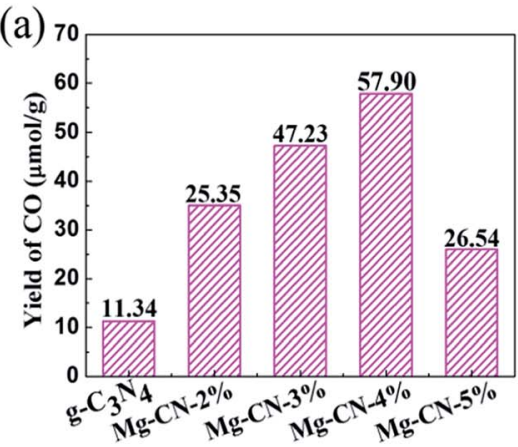

(b)

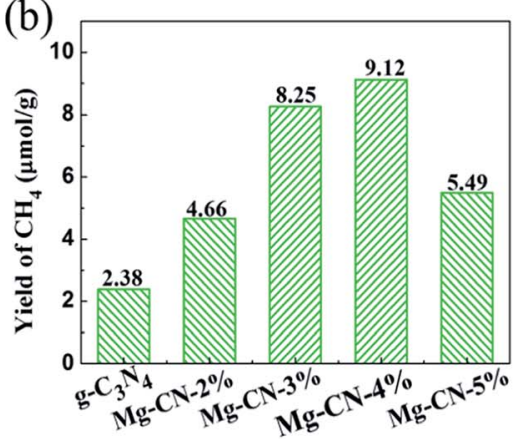

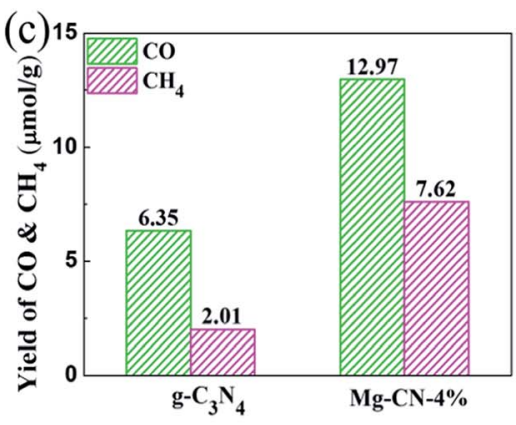

Fig. 5 UV-light photocatalytic activity of $\mathrm{g}-\mathrm{C}_{3} \mathrm{~N}_{4}$ and $\mathrm{Mg}$-doped g- $\mathrm{C}_{3} \mathrm{~N}_{4}$ samples (a) the yield of $\mathrm{CO}$, (b) the yield of $\mathrm{CH}_{4}$; (c) visible-light activity of $\mathrm{g}-\mathrm{C}_{3} \mathrm{~N}_{4}$ and $\mathrm{Mg}-\mathrm{CN}-4 \%$.

\section{Conclusion}

In summary, a facile one-pot strategy is used for the fabrication of $\mathrm{Mg}$-doped $\mathrm{g}-\mathrm{C}_{3} \mathrm{~N}_{4}$ which exhibit considerable UV-light and visible-light photocatalytic $\mathrm{CO}_{2}$ reduction activity. The optimum amount of the dopant was discovered to be $4 \mathrm{wt} \%$, and its yield of $\mathrm{CO}$ and $\mathrm{CH}_{4}$ were about 5.1 and 3.8 times that of pristine $\mathrm{g}$ $\mathrm{C}_{3} \mathrm{~N}_{4}$ under UV-light, and reached 12.97 and $7.62 \mu \mathrm{mol} \mathrm{g}{ }^{-1}$ under visible light irradiation. Such kind of enhancement could be attributed to the increased light utilization efficiency as well as the promoted photo-induced charge carrier separation due to the narrowed down band gap and introduced midgap states after effective $\mathrm{Mg}$ doping. This work is expected to open up a new insight to design highly active metal-free photocatalysts for solar-light-driven $\mathrm{CO}_{2}$ reduction.

\section{Experimental}

\section{Preparation of bulk $\mathrm{g}-\mathrm{C}_{3} \mathrm{~N}_{4}$}

A certain amount of melamine was weighed into a crucible, and calcined in a muffle furnace at $550{ }^{\circ} \mathrm{C}$ for $4 \mathrm{~h}$ at a heating rate of $2.5{ }^{\circ} \mathrm{C} \min ^{-1}$. After cooling to room temperature, the yellowcolored product was grounded into powder.

\section{Synthesis of Mg-doped $\mathrm{g}-\mathrm{C}_{3} \mathrm{~N}_{4}$ catalysts}

$6.3 \mathrm{~g}$ of melamine and a certain amount of $\mathrm{MgCl}_{2} \cdot 6 \mathrm{H}_{2} \mathrm{O}$ were dissolved in $80 \mathrm{~mL}$ of an alcohol-water mixed solution $(2: 1$ by volume), and ultrasonically dispersed for $1 \mathrm{~h}$, followed by $3 \mathrm{~h}$ stirring. The mixture was then dried at $80{ }^{\circ} \mathrm{C}$ to remove the solvent. Finally, the solid mixture was placed in a crucible and calcined at $550{ }^{\circ} \mathrm{C}$ for $4 \mathrm{~h}$ in a muffle furnace. After cooling to room temperature, it was grounded into powder. The synthesized product is labeled as $\mathrm{Mg}-\mathrm{CN}-X$, where $X$ is the molar ratio of $\mathrm{Mg}$ to melamine $(X=2 \%, 3 \%, 4 \%, 5 \%)$.

\section{Characterization}

X-Ray diffraction (XRD) patterns were carried out by an Ultima IV X-ray diffractometer. The scanning electron microscopy (SEM) analyses were conducted using a Quanta 3D FEG apparatus. Transmission electron microscopy (TEM) image was obtained by a JEM-2100 microscope. Fourier transform infrared (FTIR) spectrum was performed on a Nicolet iS50. X-ray photoelectron spectroscopy (XPS) was acquired in Thermo scientific ESCALAB 250Xi X-ray photoelectron spectrometer. The UV-vis diffuse reflectance spectroscopy (DRS) of the samples was measured using an Agilent Cary 5000 spectrometer. The photoluminescence (PL) spectrum of the samples were measured with an F-4600 fluorometer at excitation wavelength of $325 \mathrm{~nm}$. Time-resolved photoluminescence spectra of samples were recorded on a FLS920 Full-featured fluorescence spectrometer at excitation wavelength of $330 \mathrm{~nm}$.

\section{Photoelectrochemical measurements}

The photocurrent was measured by using a CHI1030B electrochemical workstation in a standard three-electrode system. A $300 \mathrm{~W}$ xenon lamp was used to provide visible light. For the prepared working electrode, $10 \mathrm{mg}$ of the obtained sample was dispersed in ultrapure water, then $1 \mathrm{~mL}$ of Nafion solution (0.5 wt $\%$ ) was added. $10 \mu \mathrm{L}$ of the suspension was dropped on fluorine-doped tin oxide (FTO) glass, and dried at room temperature. Mott-Schottky plots were measured on the abovementioned three-electrode system with a frequency of $1000 \mathrm{~Hz}$. The electrochemical impedance spectroscopy (EIS) of samples was performed by using a CHI760D with potassium ferricyanide solution as electrolyte solution.

\section{Photocatalytic experiment}

The photocatalytic $\mathrm{CO}_{2}$ reduction of the samples was carried out in a self-made rectangular reactor. Firstly, $20 \mathrm{mg}$ of the catalyst was plated on the bottom of the reactor, then high purity $\mathrm{CO}_{2}$ (99.999\%) was passed through a water vapor reactor at a flow rate of $15 \mathrm{ml} \mathrm{min}^{-1}$. In order to exhaust air, the mixed gas $\left(\mathrm{CO}_{2}\right.$, $\mathrm{H}_{2} \mathrm{O}$ ) was passed through the photocatalytic reactor for 20 minutes. Finally, close the air outlet, then reduce the flow rate and stop ventilation after 10 minutes. The $300 \mathrm{~W}$ xenon lamp was used to provide the UV light and visible light. After irradiation for $8 \mathrm{~h}$, the mixed gas in the reactor was analyzed by a gas chromatograph. 


\section{Conflicts of interest}

There are no conflicts to declare.

\section{Acknowledgements}

This work was supported by the National Natural Science Foundation of China (No. 51702014) and the Fundamental Research Funds for the Central Universities (FRF-AS-17-002).

\section{References}

1 C. Hu, W. Hung, M. Wang and P. Lu, Carbon, 2018, 127, 374. 2 Z. Sun, H. Wang, Z. Wu and L. Wang, Catal. Today, 2018, 300, 160.

3 G. Liao, J. Fang, Q. Li, S. Li, Z. Xu and B. Fang, Nanoscale, 2019, 11, 7062.

4 A. Fujishima and K. Honda, Nature, 1972, 238, 37.

5 A. Khalilzadeh and A. Shariati, Sol. Energy, 2018, 164, 251.

6 W. Li, G. Wang, Y. Feng and Z. Li, Appl. Surf. Sci., 2018, 428, 154.

7 J. Hu, H. Li, C. Huang, M. Liu and X. Qiu, Appl. Catal., B, 2013, 598, 142.

8 J. Wen, J. Xie, X. Chen and X. Li, Appl. Surf. Sci., 2017, 391, 72. 9 M. Zhou, J. Chen, C. Hou, Y. Liu, S. Xu, C. Yao and Z. Li, Appl. Surf. Sci., 2019, 470, 908.

10 M. Zhang, Z. Luo, M. Zhou, G. Zhang, K. A. Alamry, L. A. Taib, A. M. Asiri and X. Wang, Appl. Catal., B, 2017, 210, 454.

11 B. Fang, A. Bonakdarpour, K. Reilly, Y. Xing, F. Taghipour and D. P. Wilkinson, ACS Appl. Mater. Interfaces, 2014, 6, 15488.

12 G. Liao, Y. Gong, L. Zhang, H. Gao, G. Yang and B. Fang, Energy Environ. Sci., 2019, DOI: 10.1039/C9EE00717B.

13 D. Huang, Z. Li, G. Zeng, C. Zhou, W. Xue, X. Gong, X. Yan, S. Chen, W. Wang and M. Cheng, Appl. Catal., B, 2019, 240, 153.

14 S. Hu, L. Ma, J. You, F. Li, Z. Fan, G. Lu, D. Liu and J. Gui, Appl. Surf. Sci., 2014, 311, 164.

15 Y. Zeng, H. Li, J. Luo, J. Yuan, L. Wang, C. Liu, Y. Xia, M. Liu, S. Luo, T. Cai, S. Liu and J. C. Crittenden, Appl. Catal., B, 2019, 249, 275.

16 J. Tang, R. Guo, W. Zhou, C. Huang and W. Pan, Appl. Catal., $B, 2018,237,802$.

17 M. Zhou, G. Dong, F. Yu and Y. Huang, Appl. Catal., B, 2019, 256, 1037.

18 G. Li, B. Wang, J. Zhang, R. Wang and H. Liu, Appl. Surf. Sci., 2019, 478, 1056.

19 Z. Xiong, H. Wang, N. Xu, H. Li, B. Fang, Y. Zhao, J. Zhang and C. Zheng, Int. J. Hydrogen Energy, 2015, 40, 10049.

$20 \mathrm{~J}$. Wu, N. Li, X. Zhang, H. Fang, Y. Zheng and X. Tao, Appl. Catal., B, 2018, 226, 61.

21 Y. Wang, S. Zhao, Y. Zhang, J. Fang, Y. Zhou, S. Yuan, C. Zhang and W. Chen, Appl. Surf. Sci., 2018, 440, 258.

22 S. Le, T. Jiang, Q. Zhao, X. Liu, Y. Li, B. Fang and M. Gong, RSC Adv., 2016, 6, 38811.
23 N. Wang, J. Wang, J. Hu, X. Lu, J. Sun, F. Shi, Z. Liu, Z. Lei and R. Jiang, ACS Appl. Energy Mater., 2018, 1, 2866.

24 J. Wang, C. Cui, Q. Kong, C. Ren, Z. Li, L. Qu, Y. Zhang and K. Jiang, Chem. Eng. J., 2019, 359, 723.

25 S. C. Yan, Z. S. Li and Z. G. Zou, Langmuir, 2010, 26, 3894.

26 Y. Zhou, L. Zhang, W. Huang, Q. Kong, X. Fan, M. Wang and J. Shi, Carbon, 2016, 99, 111.

27 G. Liu, P. Niu, C. Sun, S. C. Smith, Z. Chen, G. Lu and H. Cheng, J. Am. Chem. Soc., 2010, 132, 11642.

28 M. Bellardita, E. I. García-López, G. Marcì, I. Krivtsov and J. R. García, Appl. Catal., B, 2018, 220, 222.

29 Y. Hong, Y. Jiang, C. Li, W. Fan, X. Yan, M. Yan and W. Shi, Appl. Catal., B, 2016, 180, 663.

30 M. Wang, M. Shen, L. Zhang, J. Tian, X. Jin, Y. Zhou and J. Shi, Carbon, 2017, 120, 23.

31 M. Li, L. Zhang, M. Wu, Y. Du, X. Fan, M. Wang, L. Zhang, Q. Kong and J. Shi, Nano Energy, 2016, 19, 145.

32 L. Zhou, L. Wang, J. Lei, Y. Liu and J. Zhang, Catal. Commun., 2017, 89, 125.

33 B. Fang, Y. Xing, A. Bonakdarpour, S. Zhang and D. P. Wilkinson, ACS Sustainable Chem. Eng., 2015, 3, 2381.

34 L. Ye, D. Wu, K. H. Chu, B. Wang, H. Xie, H. Y. Yip and P. K. Wong, Chem. Eng. J., 2016, 304, 376.

35 A. Kumar, R. K. Yadav, N. Park and J. Baeg, ACS Appl. Nano Mater., 2018, 1, 47.

36 J. Tang, W. Zhou, R. Guo, C. Huang and W. Pan, Catal. Commun., 2018, 107, 92.

37 S. Liu, H. Zhu, W. Yao, K. Chen and D. Chen, Appl. Surf. Sci., 2018, 430, 309.

38 Q. Yan, G. Huang, D. Li, M. Zhang, A. Pan and W. Huang, Mater. Sci. Technol., 2018, 34, 2515.

39 X. Wu, J. Cheng, X. Li, Y. Li and K. Lv, Appl. Surf. Sci., 2019, $465,1037$.

40 F. Guo, W. Shi, C. Zhu, H. Li and Z. Kang, Appl. Catal., B, 2018, 226, 412.

41 W. Fang, J. Liu, L. Yu, Z. Jiang and W. Shangguan, Appl. Catal., B, 2017, 209, 631.

42 Q. Li, Z. Sun, H. Wang and Z. Wu, J. CO ${ }_{2}$ Util., 2018, 28, 126.

43 S. Hua, L. Ma, J. You, F. Li, Z. Fan, G. Lu, D. Liu and J. Gui, Appl. Surf. Sci., 2014, 311, 164.

44 Z. Sun, J. M. Theresa Agatha Fischer, Q. Li, J. Hu, Q. Tang, H. Wang, Z. Wu, M. Hankel, D. J. Searles and L. Wang, Appl. Catal., B, 2017, 216, 146.

45 W. Oh, V. W. C. Chang, Z. Hu, R. Goei and T. Lim, Chem. Eng. J., 2017, 323, 260.

46 B. Yue, Q. Li, H. Iwai, T. Kako and J. Ye, Sci. Technol. Adv. Mater., 2011, 12, 034401.

47 E. Liu, J. Chen, Y. Ma, J. Feng, J. Jia, J. Fan and X. Hu, J. Colloid Interface Sci., 2018, 524, 313.

48 F. Raziq, Y. Qu, M. Humayun, A. Zada, H. Yu and L. Jing, Appl. Catal., B, 2017, 201, 486.

49 M. A. Behnajady, B. Alizade and N. Modirshahla, Photochem. Photobiol., 2011, 87, 1308.

50 J. Liu, H. Yang, W. Tan, X. Zhou and Y. Lin, Electrochim. Acta, 2014, 129, 459.

51 H. Huang, K. Xiao, N. Tian, F. Dong, T. Zhang, X. Du and Y. Zhang, J. Mater. Chem. A, 2017, 5, 17452. 
52 S. Pany and K. M. Parida, Phys. Chem. Chem. Phys., 2015, 17, 8070.

53 X. Wang, S. Blechert and M. Antonietti, ACS Catal., 2012, 2, 1596.

54 H. Yaghoubi, Z. Li, Y. Chen, H. T. Ngo, V. R. Bhethanabotla, B. Joseph, S. Ma, R. Schlaf and A. Takshi, ACS Catal., 2015, 5, 327.

55 L. Jiang, X. Yuan, G. Zeng, J. Liang, Z. Wu, H. Yu, D. Mo, H. Wang, Z. Xiao and C. Zhou, J. Colloid Interface Sci., 2019, 536, 17.
56 J. Ran, T. Y. Ma, G. Gao, X. Du and S. Z. Qiao, Energy Environ. Sci., 2015, 8, 3708.

57 R. Ding, S. Cao, H. Chen, F. Jiang and X. Wang, Colloids Surf., A, 2019, 563, 263.

58 W. Tu, Y. Xu, J. Wang, B. Zhang, T. Zhou, S. Yin, S. Wu, C. Li, Y. Huang, Y. Zhou, Z. Zou, J. Robertson, M. Kraft and R. Xu, ACS Sustainable Chem. Eng., 2017, 5, 7260.

59 J. Zhang, S. Liu, J. Yu and M. Jaroniec, J. Mater. Chem., 2011, 21, 14655.

60 L. Yang, J. Huang, L. Shi, L. Cao, H. Liu, Y. Liu, Y. Li, H. Song, Y. Jie and J. Ye, Appl. Catal., B, 2018, 221, 670. 